\title{
Czy rzeczywiście jesteśmy skazani na edukacyjną porażkę? Pedagogika jako narzędzie wyzwolenia uciśnionych tego świata
}

\begin{abstract}
Abstrakt
W tym artykule reprezentuję radykalne podejście do władającego kapitalistycznego systemu eksploatacji. Celem mojej analizy jest wydobycie z pedagogiki krytycznej jej konstytutywnych elementów, żeby podważyć bazowe założenia społeczeństwa napędzanego pragnieniem ciągłego zysku. Henry Giroux i Peter McLaren jako dwaj radykalni myśliciele pokazują nam drogę, w ramach której możemy odebrać edukację $\mathrm{z}$ rąk ciemiężycieli. To nie jest łatwe zadanie, ale może być dokonane, jeśli podważymy obecny system za pomocą wywrotowych praktyk. W tym zadaniu kluczowa rola musi przypaść nauczycielom, którzy powinni brać pod uwagę obecność w klasie szkolnej różnych narracji kulturowych. Klasa szkolna nie jest neutralnym miejscem, w którym nauczyciel przekazuje obiektywną wiedzę, ale również przestrzenią, w której możemy zamknąć bądź otworzyć uczniom ścieżkę prowadzącą do ich wyzwolenia poprzez pokazanie im, jak przestrzeń społeczna w ich wspólnotach jest konstruowana poprzez relacje oparte na dominujących formach władzy i wiedzy. Nauczyciele, którzy są świadomi tego, w jaki sposób szkoła skutecznie realizuje swój ukryty program podporządkowania umysłów swoich uczniów, mogą zapobiegać jego realizacji poprzez wdrażanie alternatywnych strategii nauczania. Podsumowując: szkolna klasa jest bardzo ważnym miejscem, w którym możemy zniewolić bądź wyzwolić uczniów poprzez pokazanie im krytycznej perspektywy w stosunku do obecnego systemu kapitalistycznego - jaką proponuje nam marksistowska teoria i praktyka. Tym sposobem osiągniemy kamień milowy w transformacyjnym procesie prowadzącym uciśnionych do rozpoznania ich podległej pozycji w kulturze dominującej, co umożliwi im świadome organizowanie się w walce o wolność.
\end{abstract}

Słowa kluczowe: praktyka marksistowska, pedagogika krytyczna, utowarowienie edukacji, społeczna zmiana, klasa szkolna, wywrotowa praktyka edukacyjna, emancypacja, perspektywa krytyczna.

* Doktorant, Akademia Pedagogiki Specjalnej im. Marii Grzegorzewskiej w Warszawie. 


\title{
Are we really doomed to educational failure? Pedagogy as the instrument of liberation of the oppressed of this world
}

\begin{abstract}
In this article I represent a radical approach to the existing capitalist system of exploitation. The purpose of my analysis is to extract from critical pedagogy its essential elements to undermine the basic assumptions of a society driven by constant lust for profit. Henry Giroux and Peter McLaren, as two radical thinkers, show us the way by which we can claim the system of education from the hands of the oppressors. This is not an easy task, but it can be done if we try to undermine the current system by subversive practices. In this mission, the key role must come to the teachers, who should take into account the presence of different cultural narratives in the classroom. The classroom is not only a neutral space in which the teacher communicates objective knowledge, but also a place where we can close or open for the students the path leading to their liberation by showing them how the social space in their communities is constructed through relationships based on the dominant forms of power and knowledge. Teachers, who are aware of how the school effectively implements its hidden agenda that implies the subordination of the minds of the students, can prevent its implementation by using alternative teaching strategies. To sum it up: a classroom is a very important place in which we can enslave or liberate students by showing them a critical perspective proposed by Marxist theory and practice towards the current capitalist system. In this way, we achieve a milestone in the transformative process leading the oppressed to recognize their subordinated position in the dominant culture, which empowers them to consciously organize themselves in their fight for freedom.
\end{abstract}

Keywords: Marxist practice, critical pedagogy, commodified education, social change, classroom, subversive educational practice, emancipation, critical perspective.

\section{Wprowadzenie w meandry perspektywy krytycznej w sferze edukacyjnej}

Pedagogika krytyczna jako subdyscyplina wiedzy pedagogicznej nie waha się walczyć o prawa najuboższych tego świata. Jej najważniejszymi przedstawicielami są Peter McLaren i Henry Giroux, obaj są myślicielami niezwykłymi pod wieloma względami. W tej pracy nie podejmuję się analizy całego ich dorobku, ale skupiam się na wybranych publikacjach w celu wyeksponowania tych aspektów myśli autorów, które są moim zdaniem kluczowe dla ich rewolucyjnego podejścia do teorii i praktyki edukacyjnej (nie abstrahuję też od szeroko rozumianej literatury i perspektywy neo/marksistowskiej). Jednym z najważniejszych, najbardziej rzucających się w oczy elementów ich twórczości jest przesycenie jej treściami wolnościowymi i równościowymi, które w sposób ewidentny obrazują zafascyno- 
wanie i oddanie jej twórców krytycznym analizom problematyki nierówności społecznej, walki klasowej, rasizmu, genderyzmu, dyskryminacji, homofobii, kwestii ekologicznych itp. Dla mnie osobiście największym plusem tego typu alternatywnego myślenia jest przesycenie go krytycznymi analizami, w których zarówno McLaren, jak i Giroux posługują się instrumentarium marksistowskim. Zadaniem tego tekstu jest więc nie tyle zapewnienie pełnej analizy ich twórczości, co ukazanie nowatorskich walorów intelektualnych ich myśli i zachęcenie do uwzględniania krytycznej perspektywy we własnej codziennej praktyce naukowej. Okazuje się, że w Stanach Zjednoczonych, które jak się wydaje są ostoją projektu neoliberalnej hegemonii, istnieje alternatywna perspektywa edukacyjna i społeczna, która nie waha się poruszać kwestii trudnych i kontrowersyjnych w aktualnej sytuacji politycznej w USA. Szczególnie McLaren wpisujący się w bardziej radykalny, jeśli nie wprost rewolucyjny, nurt pedagogiki krytycznej posługuje się w swojej pracy chętnie analizą marksistowską. Jest to więc twórczość bardzo ciekawa, jawnie konfrontująca się z rzeczywistością rozwiniętego kapitalizmu i pokazująca jego oczywiste i ukryte mechanizmy. Kwiecisty, literacki i bogaty język publikacji, które w końcu stały się w niewielkiej części dostępne dla polskiego Czytelnika (McLaren 2015, Giroux, Witkowski 2010), czyni ich twórczość nieobojętną także dla humanistycznego umysłu znużonego po wielokroć monotonnym i jednolitym językiem wielu naukowych rozpraw. W obecnym świecie coraz trudniej znaleźć próby budowania kontrhegemonicznego projektu, który sprzeciwiałby się postępującemu utowarowieniu edukacji i szkolnictwa wyższego. Wykluczenie klasowej perspektywy spowodowało oderwanie od tradycji, która jako jedyna dała tak przekonującą i inspirującą pokolenia wielkich uczonych krytykę kapitalizmu. Mowa oczywiście o marksizmie. Na szczęście część postępowych intelektualistów nie pozwoliła na to, aby hegemoniczne zwycięstwo projektu kapitalistycznego spowodowało całkowite ujarzmienie potencjałów krytycznych światowej kultury. Niewątpliwie tak gwałtowny atak na pozycje kwestionujące logikę społeczeństw rozwiniętego kapitalizmu budzi uzasadnione zastrzeżenia, gdyż mimo wypaczonego użytku, jaki uczyniła z marksizmu propaganda najpierw leninowska, a potem stalinowska, zawiera on ogromny potencjał intelektualny i rozwojowy, pozwalający ujrzeć w nowym świetle wiele mechanizmów dzisiejszego społeczeństwa konsumpcyjnego. Pedagogika krytyczna pojmuje edukację jako jeden z podstawowych obszarów walki o bardziej sprawiedliwe i egalitarne społeczeństwo jutra. To bowiem w klasie szkolnej będącej swego rodzaju laboratorium tworzy się czy raczej $\mathrm{w}$ obecnym systemie produkuje się ludzkie podmioty podporządkowane rynkowemu imperatywowi zysku za wszelką cenę. Walka o alternatywny system społeczny musi więc mieć miejsce również w przestrzeni szkolnej, która zbyt długo była strażnicą status quo neoliberalnego reżimu akumulacji przez wywłaszczenie ubogich tego świata. 


\section{Dlaczego pozytywne potencjały rozwojowe są ujarzmiane, czyli dekonstrukcja ukrytych aspektów obowiązującego reżimu władzy i wiedzy}

Perspektywa pedagogiczna odwołująca się do analizy neo/marksistowskiej zrywa z reprezentowaniem ideologii klasy panującej, myśliciele zaś, którzy wpisują się w obszar rewolucyjnej pedagogiki krytycznej, organizują praktykę i teorię w sferze edukacyjnej w taki sposób, który umożliwia wyraźne przeciwstawienie się kapitalistycznej machinie przymusu. McLaren w swojej ostatnio wydanej w języku polskim publikacji (McLaren 2015) prezentuje pasjonujący opis, który w formie dziennika dokumentuje jego doświadczenia jako nauczyciela w szkole podstawowej w getcie w kanadyjskim Toronto. Przedstawia tam także główne zagadnienia pedagogiki krytycznej. Warto zwrócić uwagę, że poddaje on analizie własną praktykę edukacyjną, przebiegającą skądinąd w naprawdę ekstremalnych warunkach. Pokazuje to, że analiza krytyczna własnego postępowania pozwala nam często na ukazanie ukrytych aspektów oddziałującej na nas fałszywej świadomości ideologicznej, narzucanej nam przez obowiązującą hegemonię. Wnikliwa analiza amerykańskiego, globalnego społeczeństwa i ukazywanie jego skrywanych, negatywnych potencjałów rasistowskich jest jedną z wyraźnych cech współczesnej pedagogiki krytycznej. Zaatakowanie uświęconych kategorii kapitalistycznej propagandy takich jak własność prywatna czy specyficznie rozumiana wolność indywidualna, w połączeniu z dekonstrukcją ukrytej kategorii białości, pozwala na wytyczenie możliwych przyszłych kierunków rozwoju amerykańskiego i światowego społeczeństwa oraz zaproponowanie alternatywnej, kontrhegemonicznej drogi. Sam McLaren przyznaje się do swojego pierwotnego ideologicznego uwarunkowania i tego, że odczuwa niezadowolenie z pierwotnej wersji swojej publikacji ${ }^{1}$ (tamże: 17-19). Od czasu pierwszego wydania w 1980 r., w następnych wersjach została ona poszerzona o rozbudowaną część teoretyczną, która jest ciągle dostosowywana do zmieniających się uwarunkowań społeczno-politycznych i aktualnego stanu własnych badań. Z biegiem czasu jego poglądy jako pedagoga i krytycznego obserwatora codziennej rzeczywistości coraz to bardziej się radykalizowały, aż w końcu odniósł się do pozycji marksistowskich (nie leninowskich bądź stalinowskich - nie utożsamiajmy myśli Marksa z jej późniejszymi wypaczeniami, to tak jakbyśmy utożsamiali wszystkie zbrodnie popełnione w imię chrześcijaństwa $\mathrm{z}$ naukami Jezusa obecnymi $\mathrm{w}$ Biblii) połączonych $\mathrm{z}$ podejściem reprezentowanym przez teorię krytyczną. Obnażanie stosowanych w szkołach w sposób nieświadomy edukacyjnych praktyk hegemonicznych, których dopuszcza się również duża część, jeśli nie większość, polskich nauczycieli, wykluczających w ten sposób znaczną grupę uczniów z życia codziennego szkoły, jest zadaniem każdego krytycznie zorientowanego transformatywnego intelektualisty. Pamiętajmy jednak o tym, że każda praktyka, choćby nie

${ }^{1} \mathrm{Na}$ początku był to sam dziennik bez żadnej analizy. 
wiem jak doskonała, jest wtórna i zależna od skrytych w mrokach świadomości zbiorowej koncepcji teoriopoznawczych, jakie bezwolnie akceptujemy, aby zyskać połączenie z otaczającą nas rzeczywistością. Ten swoisty paradygmat, te wdrukowywane nam oprogramowanie w sposób niezwykły warunkuje nasze przyszłe dokonania. Aby uzyskać realny wpływ na edukacyjną praktykę, musimy więc dokonać swoistego podważenia świata nadpisywanego $\mathrm{w}$ naszych umysłach, a jawiącego się nam jako oczywisty i niepodlegający dyskusji całościowy konstrukt. Każdy człowiek wychowany, a więc zindoktrynowany przez obowiązującą ideologię konsumpcjonizmu musi pokonać tę samą drogę, którą postępował wcześniej McLaren, aby uwolnić się od nieuświadamianych schematów, jakie wgrano nam w procesie uwewnętrzniania propagandy utowarowionej edukacji i zastąpić je nowym, twórczym podejściem, uwzględniającym postulaty egalitaryzmu społecznego i troski o dobro wspólne (tamże: 17). W terminologii marksistowskiej te narzucone nam schematy postrzegania nazywa się fałszywą świadomością ideologiczną, której barierę członkowie uciśnionego demosu (kiedyś proletariat teraz w krajach wysoko rozwiniętych np. prekariat) muszą pokonać, aby podążać ścieżką wyzwolenia. Nadzieja ginie ostatnia, zmagazynowana przez stulecia wyzysku wściekłość jest jak długi okres suszy, po którym jedna iskra, jedno brutalne zachowanie autorytarnego oprawcy może spowodować bunt.

Pozbyć się bowiem wcześniejszego habitusu, charakterystycznego dla dominującej arbitralności kulturowej można tylko poprzez jego swoiste przeformatowanie, dekonstrukcję, a nawet dezintegrację. Da się to wyjaśnić na przykładzie niewspółmierności paradygmatów - paradygmat astronomii kopernikańskiej nie daje się wpisać w obręb astronomii Ptolemeusza - są one logicznie sprzeczne. Aby więc dokonać samowyzwolenia z ukrytych sieci ideologicznych zniewalających i ograniczających nasze twórcze myślenie, musimy zakwestionować sam sposób własnego postrzegania rzeczywistości. Obowiązująca hegemonia neoliberalna rekonstruuje się i odtwarza poprzez system nauczania zinstytucjonalizowanego. Reprodukcja społeczna i kulturowa postępuje, wytwarzając coraz to nowe podporządkowane jej umysły. To, co uznajemy za ważne i wartościowe lub na odwrót, zostaje nam w tym procesie często bezpowrotnie wpojone, a my sami jedynie w wyniku ciężkiej pracy emocjonalnej i intelektualnej możemy przepiąć własne afekty i ścieżki myśli w taki sposób, który będzie bliższy naszemu własnemu postrzeganiu rzeczywistości, w jakiej żyjemy.

Ponieważ PP jest procesem nieodwracalnym, wytwarzającym $\mathrm{w}$ czasie niezbędnym do jej wpojenia nieodwracalną dyspozycję, która sama może być stłumiona bądź przeobrażona jedynie dzięki nieodwracalnemu procesowi wytwarzającemu z kolei nową nieodwracalną dyspozycję, pierwotne DP (wychowanie podstawowe) dopełniające się $\mathrm{w}$ niczym niepoprzedzonej PP (PP pierwotna) wytwarza pierwotny habitus, charakterystyczny dla grupy lub klasy, 
który jest u podstaw późniejszego kształtowania wszelkich innych habitusów (Bourdieu, Passeron 2006: 121).

Członkowie społeczności podporządkowanych stoją więc przed radykalnym wyborem - albo absolutna konwersja i wyparcie się poprzez tresurę zakładającą określone DP własnej kultury środowiska rodzinnego, albo pogodzenie się z własną podrzędną pozycją i zajęcie określonego miejsca w hierarchii społecznej. W każdym z tych dwóch przypadków są przegrani: w pierwszym bowiem muszą zamordować własną duszę (termin Wilhelma Reicha), a w drugim są skazani na powielanie ograniczeń własnych ojców i matek.

Nie tylko więc McLaren, ale i wszyscy członkowie demosu będący wdrożeni w obecny system utowarowiania naszego człowieczeństwa podporządkowują swoje codzienne funkcjonowanie, a więc schematy i ścieżki łączące ich z kulturą i nauką danego społeczeństwa meandrom neoliberalnej logiki urynkowienia i odhumanizowania politycznej sfery demokratycznej na rzecz bezlitosnej ekonomicznej gry, w której o byciu lub niebycie decyduje wygrana w procesie „wolnej” konkurencji. Niestety więc po dziś dzień społeczeństwa rozwiniętego kapitalizmu tkwią w świecie nieuświadamianego poddaństwa, a nawet jeśli to za ostre sformułowanie, to pozostają one w nieświadomości tego, jak nasze obserwacje są warunkowane przez wbudowane nam schematy teoriopoznawcze. Znakomitym przykładem analizy obrazującej skutki tego pierwotnego ideowego zapisu warunkującego nasze przyszłe dokonania są prace takich badaczy, jak Thomas Kuhn (2009), Paul Feyerabend (1996), Karl Raimund Popper (1997) - którzy zajmują się problematyką paradygmatu w nauce, rewolucji naukowej i odkrycia naukowego. McLaren doszedł do tego samego wniosku za pomocą tradycji pedagogiki krytycznej, jak i tradycji marksistowskiej. Tak więc żadna idea nie jest bezstronna, jesteśmy subiektywni aż do bólu i istniejemy w pewnym polu kulturowym, które podpowiada nam, co jest zasadne, a co takim nie jest. Wszystkie teorie, idee są zależne zarówno od obowiązującego schematu, jak i od filtrów ideologicznych obecnych w naszych głowach. Jak przyznaje ten jeden z głównych przedstawicieli tradycji krytycznej na terenie pedagogiki:

Nic, co da się zaobserwować albo nazwać, nie jest ideologicznie neutralne ani niewinne. Żadna myśl, idea czy teoria nie jest autonomiczna, nie unosi się swobodnie ponad gęstą siecią stosunków produkcji i konsumpcji. Kto twierdzi, że jest inaczej, dopuszcza się mistyfikacji typowej dla klasy średniej, wciska innym starą bajkę, służącą ukrywaniu określonych interesów (McLaren 2015: 19).

Radykalizacja światopoglądowa i nastawienie krytyczne do obowiązującego status quo są niezwykle istotne w rzeczywistości społeczeństw ogłupiałego konsumeryzmu. Przestrzeń uniwersytetu, który powinien być matrycą wymiany rozmaitych 
idei została zawłaszczona przez neofundamentalistyczne siły przymierza korpokracyjno-militarystycznego traktującego ją jak proste przedłużenie utowarowionej edukacji. Walka o akademickie wolności, które zaczynają być ostatnim bastionem realnej wolności wypowiedzi i kwestionowania obecnego porządku musi być połączona z obroną tradycji demokratycznej i ideałami poszanowania godności i wartości każdego człowieka jako obywatela danego państwa. Nauczyciele i pedagodzy, którym nieobojętny jest los demokracji, muszą walczyć o tych wykluczonych, dla których nie ma miejsca w neoliberalnym projekcie ekonomicznej restauracji władzy klasowej elit. Edukacja stała się burżuazyjnym systemem w tym sensie, że ideały demokratyczne takie jak dobro wspólne i społeczna solidarność zostały w niej zastąpione postulatami wykorzystania produkcji/edukacji dla potrzeb akumulacji kapitału. Patrząc na realia polskiej szkoły publicznej, w której mamy do czynienia również z legitymizacją jednego słusznego dyskursu, w której obowiązuje wyścig szczurów, a pozornie bezpłatna oświata przygotowuje do pracy na umowach śmieciowych, trudno oprzeć się poczuciu rezygnacji, tym bardziej że państwo całkowicie niemal ignoruje obywateli. Amerykanie mają przynajmniej swojego McLarena i Giroux, którzy nie boją się powiedzieć otwarcie, do czego służy państwowa edukacja. W Polsce, co przykre, również następuje atrofia wolności i swobód akademickich, postępuje wkraczanie żelaznych prawideł rynku i kto wie, czy kiedyś wszystkie uczelnie nie znajdą się na garnuszku burżuazyjnych poliglotów. Neoliberalna ideologia w coraz większym stopniu wkracza w sferę akademicką, doprowadzając do uformowania jej na kształt supermarketu pełnego wiedzy, mającego spełnić określone oczekiwania klientów i rynku pracy. Zagraża to w rosnącym stopniu rozwojowi tradycji demokratycznej i powoduje daleko idące konsekwencje dla interakcji międzyludzkich.

W słowniku neoliberalizmu to, co publiczne, pokrywa się z tym, co osobiste [personal] (...) Rynek obecnie wydobywa na plan pierwszy wagę prywatnych interesów, wraz z ukrywaniem trosk publicznych, nieustannie rozpraszając nawet szczątkowe poszanowanie dobra publicznego i więzi uspołecznienia i wzajemności (Giroux 2010: 270-271).

Henry Giroux, którego współpracownikiem jest McLaren (na jego zaproszenie przyjechał do USA z rodziną), w swoich publikacjach również uświadamia nam, że żyjemy w strukturach władzy, które są często ukryte pod pozornie wolnościowymi praktykami i sformułowaniami. Okazuje się, że jest coś takiego jak granica wolności słowa, a wolnościowe wypowiedzenie posłuszeństwa zaborczemu państwu nie jest możliwe bez rewolucyjnej walki klasowej. Dzieje się tak, ponieważ nowoczesne państwo kapitalistyczne, demokracja kapitalistyczna nie służą wcale obywatelom i nie mają zamiaru pozwalać im na obywatelskie nieposłuszeństwo (termin Thoreau). Służą one interesom nielicznych grup elity kapitalistycznej, która czerpiąc zyski z namnażającego się kapitału i wchodząc w koalicje z politykami, nie zgadza się na 
demokratyczne i wolnościowe praktyki reform lub całkowitej zmiany schematów i struktur władzy. To, że zarówno Giroux, jak i McLaren nie odwracają się od terminologii marksistowskiej i nie boją się obrażać uświęconych tradycją poglądów (Feyerabend) zasługuje na szacunek. Ci, którzy twierdzą, że instrumenty dostarczone nam przez Karola Marksa są przestarzałe i opierają się na doświadczeniach polskich okresu PRL-u bądź utożsamiają jego twórczość z późniejszymi poglądami Lenina lub Stalina należy odesłać do jego dzieł, które są ewidentnym świadectwem błędności takiego stylu myślenia. Walka o demokratyczne swobody w obrębie sfery publicznej musi być powiązana z uwolnieniem edukacji od dominanty ekonomicznej na rzecz sfery politycznej. Jest to tak ważne, ponieważ jedynie poprzez bezpośrednie zaangażowanie i wolnościowe myślenie w tym obszarze można formułować demokratyczne postulaty wolności, równości i egalitaryzmu. Dbałość o to, żeby wspólne nam wszystkim dobro wspólne nie zostało utowarowione i zaprzęgnięte do służby w imię interesów konglomeratu przemysłowo-finansowego jest niewątpliwie istotnym działaniem $\mathrm{w}$ obronie przed popadnięciem $\mathrm{w}$ autorytarną wersję kapitalizmu, który nie potrzebuje już więcej obniżającej jego zdolność do akumulacji kapitału fasady demokratycznej. Przebudowa szkoły w ramach modelu rynkowego ciągle postępuje, język parametryzacji, utestowienia i uprzedmiotowienia wdziera się w zawrotnym tempie we wcześniej chronione i cieszące się dużą autonomią obszary kultury i nauki. Już nie tylko sfera polityczna, ciało ludzkie, ale nawet i język, i wiedza podlegają procesowi utowarowienia. Wskaźniki wydajności i efektywności nie mogą być priorytetami w świecie, w którym żyjemy, ponieważ powoduje to podporządkowanie życia ludzkiego potrzebie ciągłego namnażania zysku bez względu na konsekwencje $\mathrm{z}$ tym powiązane, takie jak zniszczenie środowiska naturalnego i osłabienie zarówno wewnętrznych, jak i zewnętrznych relacji interpersonalnych między ludźmi. Studenci nie mogą stać się jedynie konsumentami bezkrytycznie przełykającymi obowiązkowe pigułki wiedzy, aby dostać odpowiednie uprawnienia na rynku pracy. Z drugiej strony naukowcy w coraz większym stopniu stają się obwoźnymi sprzedawcami w nieautentyczny sposób reklamującymi swoją pracę i co więcej, dostosowującymi swoje poglądy i treść własnych prac do wymogów obecnie obowiązującej neoliberalnej hegemonii. Stopniowo utrudnia się jednostkom pochodzącym $\mathrm{z}$ uboższych warstw/klas społecznych uzyskanie awansu społecznego. Niejawne opłaty edukacyjne, wprowadzanie odpłatności na studiach powodują, że w coraz większym stopniu nauczyciele akademiccy i ci od szkolnictwa podstawowego stają się, chcąc czy nie chcąc, stróżami obecnego reżimu władzy i wiedzy. Zanika w rosnącym stopniu angażowanie się w aktualnie toczące się spory, uczniowie, studenci zostają zredukowani do roli bezkrytycznych odbiorców gotowych „dawek” wiedzy. Zajęcia odrabia się tak samo jak kiedyś odrabiało się pańszczyznę w szlacheckiej Rzeczypospolitej. Język techniczny, utylitarystyczny zaczyna przenikać do prac naukowych, których twórcy stają się w nieświadomy sposób obrońcami obowiązującego status quo (Levidow 2009: 256). 
Zamierzenia neoliberałów można ogólnie opisać jako urynkowienie szkolnictwa wyższego, tj. przebudowa jego formy i treści wedle modeli rynkowych. Co prawda, tylko niektóre formy urynkowienia zmieniają edukację w towar, wszystkie jednak wprowadzają buchalteryjne kryteria oceny kształcenia i jego produktów - ludzi. Metafora „inwestycji” łatwo nabiera dosłowności: uczelnie i ich personel mogą być rozliczane z mierzalnej „dywidendy”, jaką oferują (tamże: 255).

Nie powinniśmy więc zapominać o tym, że klasa szkolna jest swoistym laboratorium, w którym relacje odzwierciedlają społeczne nierówności. Stratyfikacja społeczna postępuje już na podstawowym poziomie edukacji. Kultury podporządkowane są w niej ukazywane jako bezwartościowe w porównaniu z kulturą dominującą. Nieodpowiednia muzyka, strój, sposób gestykulacji i wysławiania się są od razu piętnowane, co $\mathrm{w}$ połączeniu z dyferencjacją ekonomiczną skutkuje natychmiastowym odebraniem arbitralnościom kulturowym grup podporządkowanych własnej godności. Należy zastanowić się, jak sprawić, by niejawne preferencje obecnego systemu klasowego były choćby częściowo niwelowane przez wprowadzanie większego egalitaryzmu i dowolności w kształceniu początkowym. Nie jest to niestety możliwe i nie będzie bez krytycznej analizy naukowej mechanizmów szkolnych, prowadzonej przez nauczycieli/transformatywnych intelektualistów. Zadaniem oświaty powinno być bowiem podnoszenie poziomu świadomości społecznej, a tym samym oddziaływanie na jakość wspólnoty obywatelskiej i jej kultury, co w połączeniu z szeroką jej dostępnością będzie skutkować nasileniem w powstawaniu nowych ruchów społecznych aktywnie sprzeciwiających się obecnemu stanowi niesprawiedliwości i nierówności i formułujących w przestrzeni publicznej postulaty reform.

Rzeczywistość społeczna nie tworzy się w toku kumulatywnego rozwoju, wynika z ciągłej i nieustającej walki. Ścieranie się różnorodnych interesów ideologicznych, klasowych, ekonomicznych nie omija wcale samej przestrzeni szkoły. Zarówno klasa szkolna, jak i szkoła są wypełnione uprzedzeniami, rasizmem i dyskryminacją. Rewolucyjna pedagogika krytyczna ma na celu uświadomienie nauczycielom, rodzicom i ich uczniom, że ta przestrzeń, która wydaje im się neutralna, nigdy taką nie była i nie będzie. Edukację można więc analizować w sposób krytyczny i pokazywać, że proces nauczania wcale nie jest tak oczywisty, jak mogłoby się wydawać, a często bardziej ma na celu szkodzenie i wykluczanie osób pochodzących z określonych grup społecznych niż jakąkolwiek im pomoc (McLaren 2015: 20).

Cała praca McLarena przeniknięta jest myślą przewodnią, która zakłada, że całkowite niemal zanegowanie dorobku teorii marksistowskiej w obrębie pedagogiki i powiązanej z nią walki o wyzwolenie społeczne jest błędne i prowadzi do jej odrzucenia jako bezsensownej oraz wygodnego ignorowania przez klasę panującą ciągle trwającej walki ogromnych rzesz ludzkich o to, aby godnie żyć i pracować. 
Opinię taką, z którą skądinąd się zgadzam, potwierdza Francis Wheen, który w swojej książce Marks Kapitał. Biografia twierdzi:

Głównym celem mojej książki jest przekonanie przynajmniej części tych czytelników, żeby spojrzeli na dzieło Marksa jeszcze raz: każdy, kto chce zmagać się z Beethovenem, Goyą czy Tołstojem, będzie mógł się „czegoś nowego nauczyć" z lektury Kapitału. Także dlatego, że jego przedmiot wciąż rządzi naszym życiem. Marshall Berman pyta: „Jak mógłby się skończyć Kapitał, skoro kapitał nadal żyje?" (Wheen 2007: 11).

Wydaje się, że teraz bardziej niż kiedykolwiek wcześniej teorie Marksa stają się aktualne. Zjawiska społecznych niepokojów się nasilają, nad światem zawisła groźba trzeciej wojny światowej, nierówności między najbogatszymi a biedotą sięgają zenitu. To nie przypadek, jak twierdzi nasz radykalny pedagog, że następuje nasilenie nastrojów nacjonalistycznych, groźnie patriotycznych w największym imperium świata i po dziś dzień niepodważalnego globalnego hegemona, jakim jest United States of America. Nikomu, kto posiada jakąś przeciętną racjonalność, nie wyda się sprawiedliwe to, że 85 osób ${ }^{2}$ posiada większy majątek niż połowa ziemskiej populacji. Paradoksalnie rządząca elita, która coraz bardziej ogranicza się do wąskich grup interesów, pomimo ciągłego umacniania własnej pozycji panicznie boi się odrzucenia. Można zacząć się zastanawiać, czy budowanie pewnego rodzaju dyskursu fobii, dyskryminacji, rasizmu w skrajnie skomercjalizowanym społeczeństwie, jakim jest USA, nie jest tak naprawdę rodzajem społecznej sublimacji niewygodnych żądań i próbą przeniesienia ich na łono kultury, aby nie dopuścić na ich analizowanie z perspektywy klasowej. Zjednoczenie się uciśnionych $\mathrm{w}$ ich walce przeciwko rosnącemu wyzyskowi i wyartykułowanie postulatów odwołujących się do dziedzictwa rewolucji francuskiej musi być rzeczywiście jednym z najgorszych snów każdego neoliberalnego zeloty (McLaren 2015: 228).

\section{W jaki sposób obecny system kapitalistyczny tworzy, umacnia oraz uzasadnia swoją władzę klasową?}

W literaturze krytycznej odwołującej się do teorii neomarksistowskich, którą tutaj się zajmuję, kapitalizm jest przedstawiony jako główne zło doprowadzające społeczeństwa całego świata do stanu permanentnej nierówności pomiędzy ludźmi. Wielu czytelników, którzy są niezaznajomieni ze spojrzeniem na rzeczywistość, czerpiącym z marksistowskich nurtów teoretycznych, może być zaskoczonych tak mocno i dosadnie wyrażanymi opiniami na tak przecież podziwiany przez wielu $\mathrm{z}$ nas ponowoczesny porządek. Jednak jest to wniosek dobrze uargumentowany

\footnotetext{
${ }^{2}$ W chwili pisania tego artykułu jest to już jedynie 8 osób: https://www.theguardian.com/globaldevelopment/2017/jan/16/worlds-eight-richest-people-have-same-wealth-as-poorest-50 [09.10.2017].
} 
i osadzony w tradycji marksistowskiej, która jest odmienna od morderczych ideologii leninizmu i stalinizmu. Myśl krytyczna dostrzega niezrealizowane potencjały tradycji demokratycznej, która we współczesnym ponowoczesnym świecie uległa daleko idącemu zniekształceniu, jeśli nie atrofii. Poszukiwanie nowej formy światowej organizacji uwzględniającej potrzeby populus, czyli ludu domagającego się własnej godności i poszanowania pierwotnego prawa, wynikającego z jego konstytuującej roli $\mathrm{w}$ stworzeniu tożsamości zbiorowej jest arcypotrzebnym zadaniem w świecie nieograniczonego wzrostu nędzy i podążającego razem z nią zniewolenia. Już sam Derrida dostrzegał niewykorzystany potencjał myśli alternatywnej wobec logiki kapitalistycznej ekspansji, choć nie był bezkrytycznym jej wielbicielem. Drapieżny reżim pieniądza dehumanizuje bowiem człowieka i odziera go z jego szlachetniejszych dążeń, ustanawiając prymat zysku i strzegącego go prawa nad postulatami egalitaryzmu, dobra wspólnego i niesprostytuowanej idei wolności. Ta ostatnia wymieniona wielka idea, w imię której ludzie oddawali życie na barykadach, zmienia się w rękach piewców akumulacji kapitału i władzy najbogatszych w spoiwo łączące w sobie uzasadnienie dla skrajnej bezduszności, narcyzmu i wyzysku w imię osobistego sukcesu. Pewna mesjanistyczna wizja, zakładająca w sobie prymat nadziei i wprowadzenia w rynkowe schematy demokratycznych i ograniczających immanentną im bezwzględność narzędzi kontroli jawi się jako sensowna idea nierezygnująca z humanistycznej obrony ideałów, które nadają sens naszemu codziennemu życiu.

Jakkolwiek z punktu widzenia Derridy marksistowski internacjonalizm stanowił porażkę, mocno sygnalizował niezrealizowaną „obietnicę” ogólnoświatowych form społecznej organizacji, która mogłaby prawdopodobnie próbować rozwiązać główne zagadnienia, z jakimi zmaga się ludzkość. (...) W związku z tym apeluje o „nową międzynarodówkę, która przekształciłaby prawo międzynarodowe, jego pojęcia i zakres interwencji, tak by było ono zgodne z demokracją i prawami człowieka i by stosowało się do sfery socjoekonomicznej i było poza kontrolą państw narodowych (Tormey, Townshend 2010: 204-205).

Kapitalizm jest w obecnej chwili ideologią niepodzielnie panującą nad światem. Wmawia ludziom, że ich sukces bądź porażka zależy tylko od nich, potrzebuje ciągle nowego paliwa, nowych młodych ciał do pracy, oddziela pracę fizyczną od umysłowej i nie zwraca uwagi na doświadczenia zbiorowości społecznych, wpaja nam hierarchie władzy i przywileju, które jawią się nam jako wrodzone, choć są jedynie pewnymi możliwymi sposobami postępowania i myślenia (McLaren 2015: 28). W rzeczy samej dziedzictwo Marksa zostało zbyt szybko porzucone i nadszedł już czas, aby poszukać realnej alternatywy dla demokracji kapitalistycznej. Poglądy McLarena uległy widocznemu zradykalizowaniu, co widać w jego nowszej publikacji, nieprzetłumaczonej jeszcze na język polski, która w dużej części poświęcona 
jest Che Guevarze i jego dziełu. Książka ta o tytule: Che Guevara, Paulo Freire, and the pedagogy of revolution kontynuuje atak na kapitalistyczne struktury opresyjnej władzy i jest przykładem na dalsze radykalizowanie się myśli tego wybitnego pedagoga krytycznego. Jego radykalizm ładnie obrazuje poniższy cytat:

Moim zdaniem prawdziwymi wrogami konserwatystów i liberałów są ci, którzy nie tylko kwestionują samą istotę kapitału, lecz także domagają się utworzenia społecznego uniwersum poza nim, innymi słowy - myśliciele i działacze socjalistyczni. Główne wyzwanie nie polega na podważaniu neoliberalnych ideologii rynkowych. Kapitalizm musi wylądować na śmietniku. Musimy przedstawić dla niego alternatywę (McLaren 2015: 33-34, podkreśl. D.Ch.).

To właśnie wyróżnione przeze mnie tłustym drukiem przekonanie jest wszechobecne nie tylko w pedagogice krytycznej, ale i w całej literaturze, która czerpie swoją innowacyjność z neomarksistowskich korzeni. Stanowisko takich pedagogów krytycznych jak McLaren bądź Giroux jest jednak tym radykalniejsze, że opowiada się za zniesieniem obecnego porządku hegemonicznego, a nie jego reformizmem i daleko idącą transformacją. Chcą oni bowiem rewolucji, pragną tego, aby małe dzieci, które umierają z głodu i wycieńczenia w krajach trzeciego świata, nie musiały tego robić, aby zapanowała względna równość, oparta na wspólnocie i braterstwie, a nie pełna hipokryzji i fałszu rzeczywistość, oparta na wyzysku ludzi pracujących, niszczeniu związków zawodowych i odbieraniu im kolejnych praw obywatelskich. Chcą, aby ten świat przestał być światem, w którym małe dziecko jest żywym towarem, mającym w przyszłości wyprodukować wartość dodatkową dla pazernego kapitalisty. Trudno się temu dziwić. Widać tu też ironię losu, kiedy wydawnictwo Allyn and Bacon (Pearson) odmawia publikacji świetnie sprzedającej się książki uznanego naukowca ze względu na jej „skomplikowaną terminologię” (McLaren 2015: 29-30). Ten charakterystyczny dla radykalnych pedagogów ostry i nieprzejednany w swej krytyce styl uwidacznia się w pracy Giroux pt. Zombie politics and culture in the age of casino capitalism, w której pokazuje on to, jak szkoły, które powinny być miejscem demokratyzacji przyszłych obywateli, rozbudowywania ich poczucia wartości i czynienia ich pełnymi osobami zdolnymi do sprzeciwu wobec społecznej niesprawiedliwości i okrucieństwa, stają się w rosnącym stopniu zhierarchizowanymi i odgórnie, centralistycznie zarządzanymi instytucjami penalnymi, karzącymi uczniów za ich odmienność oraz w bezwzględny sposób wdrażającymi ich w logikę praw rynkowych, w których ich wartość jest wprost proporcjonalna do zysku, jaki potrafią wypracować dla przyszłych pracodawców. Zarówno szkoła jak i polityka są w coraz większym stopniu narzędziami w rękach nielicznych elit tego kapitalistycznego świata.

Autorytaryzm staje się wiodącym motywem, a marginalizowane klasy społeczne są spychane na obrzeża sfery publicznej i żyją pośród nieustającego strachu 
przypominającego niekiedy obawę chłopa pańszczyźnianego przed feudalnym panem dysponującym władzą życia i śmierci. W rzeczy samej od decyzji pracodawcy zależy często być i nie być licznej rodziny, dzięki czemu w sytuacji dużego bezrobocia posiada on narzędzie wywierania potężnej presji na tego, który pozostaje na jego „utrzymaniu”. Penalizujące praktyki zaczynają przenikać do szkoły, która w rosnącym stopniu zaczyna przypominać zakład karny, zaś nauczyciele doskonale wczuwają się w role strażników więziennych i dyscyplinują, poniżają i wykluczają bezlitośnie podporządkowywanych sobie uczniów. Kultura szkolna staje się kulturą więzienną, w ramach której ci biedniejsi są traktowani nie tyle jako wymagający specjalnej pomocy, ale jako potencjalni przestępcy, których trzeba kontrolować i indoktrynować. Wychowanie jako pozytywna aktywność wiodąca do wytworzenia krytycznego obywatela świadomego swoich praw i zdolnego do ich obrony w ramach podstawy demokratycznej zostało zastąpione brutalną polityką „zera tolerancji” dla jakichkolwiek wykroczeń, powodując, że głównymi ofiarami narastającej obsesji odnośnie do bezpieczeństwa stają się dzieci odmiennego koloru w szkołach, postrzegane jako tykające bomby (Giroux 2011: 124-126). Oczywiście nie zauważa się już tego, że decydujący wpływ na masakry z udziałem broni ma jej powszechna dostępności oraz propaganda militarystyczna i antyterrorystyczna nakręcana i kierowana z Waszyngtonu.

W konsekwencji duża część młodzieży, zwłaszcza pochodzenia etnicznego, w miejskim systemie szkolnym nie tylko zostaje zawieszona i wydalona ze szkoły, ale również musi znieść straszliwe brzemię bycia wprowadzonym w mroczne przybytki ośrodków karnych dla nieletnich, sądy dorosłych i więzienia (tamże: 124).

W taki to sposób logika przymusu i inkarceracji opornych zatruwa demokratyczny dyskurs, którego wartości są stopniowo podważane i zastępowane uświęceniem pustego konsumpcjonizmu oraz bogacenia się choćby i kosztem najbiedniejszych członków danego społeczeństwa.

Tworzenie realnego społeczeństwa musi być połączone z pewną przestrzenią wolności, w której panuje przyzwolenie do otwartego kwestionowania panującego porządku. Władająca epistemologia i aksjologia nie może zabraniać prawa do twórczego wglądu w panującą rzeczywistość społeczną. Edukacja jest niezmiernie istotnym elementem rozwoju społecznego ze względu na fakt, że nieświadomie bądź świadomie przekazuje nam pewne struktury ideologiczne, które my wdrażamy w życie, często nawet nie zdając sobie sprawy z narzuconych nam ograniczeń. Kwestią, która jawi się na tym polu jako zasadnicza, jest to, aby zdać sobie sprawę z własnego zniewolenia, co jest pierwszym ruchem na drodze do wyzwolenia i upełnomocnienia, czyli stania się samostwarzającym się podmiotem, analizującym siebie i rzeczywistość go otaczającą, a także świat globalny i uwarunkowania, jakie nim sterują. Nasze podmiotowości bez wątpienia nie są autonomicznymi w sensie 
uwikłania w bieżące stosunki władzy, panujące w rozwiniętym kapitalizmie. Aby zdać sobie sprawę z własnego uprzedmiotowienia, należy za wszelką cenę rozbić panujące rozróżnienie na rządzących i rządzonych, które zaważa na niemożności wytworzenia w nas rewolucyjnego sposobu myślenia i dostrzeżenia panującego wyzysku płynącego z kapitalistycznych struktur władzy. Aby społeczeństwo mogło się dalej rozwijać, konieczne jest przetworzenie panujących stosunków za pomocą klasowej rewolucji. Dzięki walce o wyzwolenie będzie mogła wreszcie ujrzeć światło dzienne podmiotowość grup uciskanych, co może w rezultacie doprowadzić do wytworzenia nowych schematów myślenia i struktur dających możliwość pokojowego współistnienia we wzajemnej równości, a także poskutkować sprawiedliwszym podziałem zagrabionych wcześniej dóbr. Dopiero wtedy ma szansę zaistnieć edukacja prawdziwa - czyli niezdominowana jakąkolwiek jedną i wyłączną perspektywą ideologiczną. Wynika z tego jasno, że aby zaistniało wolne i sprawiedliwe społeczeństwo, kapitalizm musi zostać obalony.

Inaczej mówiąc, zwolennicy pedagogiki krytycznej uważają, że demokracja liberalna, oficjalnie deklarująca naturalną równość wszystkich ludzi, tak czy inaczej wyklucza wiele grup i skazuje je na wyzysk w dominującym systemie władzy i przywileju neoliberalnego kapitalizmu. (...) Potrzebujemy demokracji bezpośredniej, znoszącej podział na rządzących i rządzonych. By ją urzeczywistnić, musimy stworzyć społeczeństwo, w którym forma wartości pracy (kapitalizm) zostanie ostatecznie zniesiona (McLaren 2015: 37).

Wiedza, która nie jest krytyczna, nie ma dużej wartości. Proces uświadomienia, zinternalizowania sobie wiedzy wymaga większej znajomości struktur jej wytwarzania, powstawania oraz refleksji na temat procesów zachodzących przy jej uprawomocnieniu. Dopiero taka pogłębiona procedura poznawania pozwala na odwołanie się do jakiejś uniwersalnej prawdy. Marks został przez współczesny świat odrzucony jako zbędny balast historii. Jednak teraz następuje rosnące zainteresowanie jego myślą, którą rozwijają coraz to nowi autorzy. Okazuje się, że myśl marksistowska jest bardzo skuteczna i wiarygodna w wyjaśnianiu zjawisk o charakterze globalnym i krajowym. Wiele inteligentnych osób zaczyna zastanawiać się, czy aby przypadkiem nie czas pójść dalej, wynaleźć coś nowego. Nikt nie zaprzecza temu, że demokracja kapitalistyczna oddała wiele zasług. Jednak spowodowała też wiele katastrof, a towarzyszący jej wyzysk i ubóstwo w krajach trzeciego świata i nie tylko dostarcza nam solidnej bazy do krytyki jej niektórych podstawowych założeń. Okazuje się, że kapitalizm i stosunki z niego wynikające doprowadzają do stopniowego różnicowania się społeczeństwa, aż wreszcie narastające różnice stają się tak wielkie, że następuje wybuch niezadowolenia mas pracujących, tych wyzyskiwanych prekariuszy. Niepohamowana dynamika kapitału nie przejmuje się problemami zwykłych ludzi, ale przecież to właśnie tacy zwykli, tak zwani przeciętni ludzie tworzą społeczeństwo. Pedagogika krytyczna ma na celu zbudowanie 
społeczeństwa niebędącego pod władaniem burżuazyjnych interesów, w którym małe dzieci mają z góry wyznaczone przeznaczenie do pracy w zakładach produkcyjnych, a dorośli ludzie trzęsą się ze strachu o pracę i są wykorzystywani i gnębieni przez własnych pracodawców. Żywy człowiek staje się towarem, w kapitalizmie umiera wartość człowieka jako stworzenia żyjącego i rozumiejącego, że żyje i kiedyś umrze. To, że z jednej strony mamy grupy miliarderów, którzy ledwie unoszą ciężar dźwiganych i wykradzionych masom pieniędzy, a z drugiej strony co parę sekund na świecie umiera z głodu dziecko nie jest ani ludzkie, ani normalne jest karygodne. Taki system mamy gloryfikować, taką śmiercią się upajać. Niech każdy czytający ten tekst wyobrazi sobie (jeśli ma) swoje dziecko umierające powolną śmiercią z głodu, proszące mamę lub tatę o jedzenie, którego nie mogą mu dać, bo go nie mają - do takich nierówności doprowadza globalny kapitał (Shaikh 2009: 73). Neoliberalizm postuluje nagą pedagogię pełną przemocy i bezwstydu wobec potrzeb szerokich mas społecznych tego świata. Dlatego tak usilnie stara się wyrugować ze sfery akademickiej narrację demokratyczną i wolnościową, zagraża ona bowiem jego dominacji w przestrzeni publicznej. Specyficzny dla neoliberalizmu kult sukcesu, uprawiany wraz ze społecznym darwinizmem powoduje, że ubodzy tego świata oraz uczniowie przejawiający niepowodzenia szkolne są ukazywani zarówno w mediach, jak i w języku potocznym jako głupi i leniwi, a więc zajmujący należne im miejsce w szeregu. Wartości humanistyczne, uniwersalna filozoficzna etyka, ukazująca doniosłość egzystencji człowieka na tym świecie to wszystko jawi się w świetle neoliberalizmu jako nieistotne. Nauczyciele akademiccy oraz studenci w rosnącym stopniu zostają relegowani do pełnienia roli obwoźnych sprzedawców reklamujących swój towar na rynkach całego świata. Liczy się efektywność, szybkość i wydajność ich pracy podporządkowanej w rosnącym stopniu imperatywowi potrzeb kapitalistów. Wolność słowa stopniowo staje się jedynie szybko blaknącym złudzeniem, a perspektywa koryfeuszy urynkowienia wszystkiego, co wcześniej wchodziło w obszar dobra powszechnego, wspólnego staje się jedynie słuszną, której jakakolwiek krytyka wskazuje automatycznie na naszą umysłową niedojrzałość.

W swojej pracy nad tworzeniem nowych podmiotów wiedzionych logiką prywatyzacji, efektywności, elastyczności, akumulacji kapitału i destrukcji państwa opiekuńczego - naga pedagogia odziera edukację z jej publicznych wartości, krytycznej treści i obywatelskiej odpowiedzialności (Giroux 2010: 281282).

O tym właśnie piszą w swoich tekstach Giroux i McLaren i z tym nie może się pogodzić rewolucyjna pedagogika. Z wyzyskiem, który nikogo nie obchodzi, z ciałami, których nikt nie opłakuje. Z nieograniczoną akumulacją kapitału, którą powodują ludzie gnani chciwością, z bezsensownym cierpieniem, które człowiek zadaje człowiekowi. Twór umysłowy i to twór błędny, jakim jest kapitalizm, wysysa 
żywotne soki ze społeczeństw świata. Należy zmienić ludzi i świat, a uczynić to można jedynie przez edukację i inwestowanie w jakość człowieka. Tego tak bardzo brakuje w Polsce. Co to za świat, w którym ludzi, współbraci traktuje się jak „śmieci” z niższej kasty tylko dlatego, że nie mają tylu pieniędzy co niektórzy wspaniali posiadacze. Co to za „chore pokraki”, które utożsamiają wartość człowieka z wielkością jego portfela. Pracownicy socjalni, policja z czego żyją, z czego się posilają - z tego, że wysługują się państwu, zajmując się jego niechcianym elementem, ludźmi, którzy nie wytrwali w kapitalistycznym wyścigu o dominację. Może powinny powstać obszary tak zwane fawele, w których ludzie będą mogli się osiedlać bez prawa własności, w których będzie można sobie pobudować budy, jakieś schronienie i żyć tak, jak chcemy żyć, bez pomocy społecznej. Dostarczałoby się tam jedynie prąd i czystą wodę. Ludzie stworzyliby sobie tam własny kodeks postępowania i żyliby wolni bez praw kapitału. Mieliby prawo do własnego wyboru w takim zakresie, na jaki nigdy nie zgodzi się społeczeństwo wiedzione prymatem konsumpcjonizmu. Funkcjonowaliby bez pouczających ich instytucji kapitalistycznego państwa i przemądrzałych „panienek” i „panów”, którzy wiedzą, co dla nich wszystkich jest tak naprawdę dobre. Takie wolne komuny powinny powstać. Należy się zacząć zastanawiać, jakie są możliwe alternatywy dla obecnego systemu władzy, co można zmienić, aby ludziom żyło się lepiej. Świat nie jest stworzony tylko dla grupy okrutnych wyzyskiwaczy, którzy zaślepiają oczy mas propagandą sukcesu. Należy zacząć się zastanawiać, jak pedagogika i edukacja są powiązane z globalnym kapitałem. Co należy zmienić w edukacji, aby stała się ona edukacją dla ludzi, a nie dla kapitału? Czemu ma służyć proces nauczania - firmom i korporacjom, czy ludziom i ich szczęściu i rozwojowi? Czy da się zbudować świat bez kapitalizmu, a jeśli tak, to, co należy na początek zrobić, aby to stało się możliwe? Jak pisze autor Życia w szkołach:

Choć globalny kapitalizm zmusił proletariuszy z krajów rozwijających się do wybierania między głodem a niedożywieniem lub między prostytuowaniem swojej siły roboczej a oporem przeciwko kapitalistycznym alfonsom, wielu ludzi z lewicowych środowisk edukacyjnych w Stanach Zjednoczonych woli emigrację wewnętrzną, woli lizać w ukryciu swoje rany lub zaszyć się w rupieciarni postmodernizmu, gdzie mogą oddawać się próżnym krytykom konsumpcji z dala od sokolego wzroku strażników kapitalizmu (McLaren 2015: 39).

Wiem, że może to zabrzmieć górnolotnie, ale walka o wolność jeszcze się nie skończyła. W erze utowarowienia człowieka to my pedagodzy mamy za zadanie walczyć. Nasze zadanie w boju o wolność, równość i braterstwo jeszcze się nie skończyło i być może nie skończy się nigdy. To co zrobił Marks, czyli wywrócenie Hegla do góry nogami, było rzeczywiście genialnym posunięciem. Ukazało się, jak wielce mylił się ten skądinąd wielki myśliciel, kiedy twierdził, że świat idei jest światem podmiotu, a nasz świat jest tylko światem przedmiotu, odbicia idei. To my 
tworzymy religię, a nie ona nas, to my jesteśmy podmiotem historii i stworzycielami naszego świata społecznego (Wheen 2007: 17).

To my stanowimy o jakości świata, w którym żyjemy. Ludzie są podmiotem historii nie zaś jej przedmiotem. Edukacja, która dąży do podporządkowania siebie siłom kapitału, dąży do uprzedmiotowienia uczniów i ich produkcji, a nie do ich rozwoju. Uczeń staje się towarem, student staje się towarem. Ludzie są jak pionki w erze kapitału.

Jak napisał [Marks] w Tezach o Feuerbachu w roku 1845 „Filozofowie rozmaicie tylko interpretowali świat; idzie jednak o to, aby go zmienić”. Już tu, jeszcze w zarodku, pojawia się fundamentalna teza Kapitału. Jakkolwiek olśniewające byłyby jego widoczne sukcesy ekonomiczne, kapitalizm pozostaje katastrofą, albowiem zamienia ludzi w towary, wymienialne na inne towary. Dopóki ludzie nie będą umieli występować jako podmiot historii, a nie jej przedmiot, nie ma ucieczki od tej tyranii (Wheen 2007: 17-18, podkreśl. - D.Ch.).

Nie chodzi o to, by odpolitycznić edukację - ponieważ wszystko jest polityczne. Marksizm i jego interpretacja kapitału staje się czymś wielkim w obecnych czasach, ponieważ nie udaje neutralności, nie określa się poprzez fałszywe przekonanie, że wszystko jest dozwolone poprzez prawdziwość jego interpretacji (McLaren 2015: 40). Zresztą wypada wspomnieć, że tak zwany fałszywy dialog naszej epoki jest czymś wymuszonym. Grzeczność, z jaką narzuca się swoje poglądy komuś innemu, stanowi tarczę obrony przed własnym zakłamaniem. Poprzez wpisywanie się w ustalony dyskurs przyzwoitości ludzie, a również nauczyciele w szkole indoktrynują integralność osobową innych osób, wtłaczając ich w ograniczone formy swego mainstreamowego myślenia. W takim wypadku odchodzenie od ugrzecznionych norm wykształconych przez konformistyczne środowisko jest brane za oznakę braku wychowania. Natomiast ukryta przemoc, z jaką narzucane są własne poglądy, uchodzi za coś, co jest właściwe i czego się od nas oczekuje jako od wychowawców.

Polityczność edukacji w Polsce nie ulega wątpliwości. Uległość, z jaką pedagodzy i nauczyciele dostosowują się do kapitalistycznego układu sił, budzi u mnie natychmiastowe skojarzenie z feudalnym sługą, który rzuca się w błoto pod nogi swego pana, aby ten mógł stąpać nogą po suchym „gruncie”. Ukryty faszyzm i szowinizm polskiej edukacji powodują, że kapitalizm staje się tworem, który w sposób z reguły nieuświadamiany dokonuje ideologicznej penetracji, wgryzając się w naiwne i ufne umysły uczniów. Szkoła powinna się stać instytucją, gdzie ścierają się różne poglądy, różne dyskursy, bez fałszywego egalitaryzmu, bez podziałów społecznych, bez sztucznie ugrzecznionego języka.

Szkoły mają za zadanie stać się miejscem, w którym udział będzie miała kultura ludu jako równoważnego dyskursu, który będzie miał prawo dopominać się o swoje prawo do głosu i do obrony swoich interesów. Nie ma jednej słusznej 
interpretacji i nie musi być. Należy konfrontować różne opinie i poglądy w procesie krytycznego dialogu i na tym polega prawdziwy proces uwolnienia szkolnictwa, a więc i wyzwolenia mas (tamże: 41).

Nie sposób zaprzeczyć, że wszyscy jesteśmy niejako samorzutnie wytwarzani przez kapitał. Chodzi mi tutaj o to, że pozycja naszych rodziców, nasz początkowy zasób finansowy warunkują miejsce, w którym znajdziemy się na drabinie społecznej. Kwestia naszych zdolności, życia osobistego, empatii jest tak naprawdę w kapitalistycznej demokracji nieistotna. Prace teoretyczne Bourdieu i odkrycie przez niego kapitału kulturowego i lingwistycznego pokazały, że władza powiązana z warstwą/klasą, z której się pochodzi ma decydujący wpływ na późniejsze osiągnięcia szkolne naszych dzieci. Dzieje się tak dlatego, ponieważ zdominowane kultury są automatycznie uznawane przez społeczeństwo za bezwartościowe, bo obowiązuje w nim inna arbitralność kulturowa. Działania pedagogiczne nie są wcale obiektywnymi i służą w przytłaczającej większości klasie kapitalistycznej. Burżuazja wykorzystuje szkołę i nauki o wychowaniu w celu uprawiania nowych poletek podporządkowanych im, nisko opłacanych pracowników ${ }^{3}$, oceny szkolne, kultura i rynek pracy, wszystko to są złożone w misterną całość struktury nakierowane na potwierdzanie symbolicznego uprawomocnienia tych, którzy eksploatują resztę społeczeństwa. Bez tego ciągłego potwierdzania ich władza nie mogłaby się utrzymać i uległaby rozproszeniu. Wiedza, a szczególnie wiedza wpajana uczniom $\mathrm{w}$ klasie szkolnej jest $\mathrm{w}$ obecnym systemie kapitalistycznym fundamentem ich zniewolenia (Bourdieu, Passeron 2006: 104-105).

W związku z tym kapitał kulturowy, który otrzymywały dzieci z rodzin znajdujących się niżej w hierarchii społecznej, jest również jedynie balastem, którego muszą się pozbyć, jeśli pragną awansować do obszaru, w którym obowiązują nie/pisane praktyki dominującej arbitralności kulturowej.

Proszę spojrzeć na jeden charakterystyczny dla stosunków kapitalistycznych fakt - własność jest rzeczą świętą, pieniądze są nie do ruszenia cokolwiek by się stało. Kościoły, religie, przekonania, śmierć, miłość, nienawiść - wszystko to nie ma znaczenia, bowiem w obecnym świecie liczy się tylko zakumulowany kapitał. Pedagogika, która nie widzi, że żyjemy w czasach, kiedy jedyną świętością stał się pieniądz, a nasze dzieci stanowią jedynie produkt wstępny, który zostaje poddany określonej obróbce nakierowanej na pewien efekt, jest pedagogiką ślepą. Nauczyciele powinni przechodzić krytyczną edukację, aby zdać sobie sprawę ze swojego ideologicznego zakorzenienia w kapitalistycznym społeczeństwie, aby stać się krytycznymi wobec samych siebie. Marks jest niezwykle przydatnym aktorem na scenie XXI w., nie jest aktorem bezbłędnym, jego rola jednak nie jest rolą boskiego

\footnotetext{
3 Pierwotne znaczenie wychowania w języku polskim odnosiło się do hodowania, odżywiania zarówno człowieka, jak i zwierzęcia (Śliwerski 2012: 25). Z tego powodu polski uczony Bronisław Trentowski proponował zastąpienie wyrazu wychowanie terminem chowanie. Kapitaliści wykorzystują edukację w celu wyhodowania, a nie wychowania uczniów. Hodowla kapitału ludzkiego i rozwijanie potencjału uczniów nie są pojęciami tożsamymi.
} 
wysłannika, lecz rolą człowieka-geniusza, który dostrzegł ukrytą strukturę kapitału i jego nienasyconą logikę. Kapitał w uwerturze marksowskiej jawi się jako stwór pożerający własne dzieci. Wydaje się więc niezwykle wartościowym proces ujawniania, rozpoznawania systemu, w którym się żyje, dostrzegania ukrytych powiązań. Budowa nowego, lepszego świata musi być oparta na zrozumieniu jego obecnego stanu i wybraniu odpowiedniego sposobu na rozwinięcie go i transformowanie na wyższy poziom. Rewolucja, do której tak nawołuje McLaren, nie wydaje mi się dobrym rozwiązaniem. Burzenie nie prowadzi ku lepszemu. Trzeba jednak się zastanawiać nad tym, co należy zmienić i jakie są tego konsekwencje. Nie chodzi tutaj o to, co jest złe, ale o to, co jest dobre. Dobry nauczyciel to nie taki, który tworzy zasady, lecz taki, który wyzwala ucznia z jego ograniczeń. Mianowice nie chodzi mu o to, aby skupiać się na tym, co w nim złe, ale raczej żeby wydobywać i umacniać w nim tak zwane dobre cechy. Zastanawiajmy się, konstruujmy nowe schematy, szukajmy rozwiązań, bo w dobie płynnej ponowoczesności i ukrytego konformistycznego dialogu trzeba zacząć szukać nowego systemu, nowej drogi, nowych wytycznych. Klucz zdaniem McLarena jest ukryty w Marksie, zatem czytajmy go i szukajmy, a nuż znajdziemy w nim zapowiedź nowego konstruktu, odmiennej myśli, która będzie cementem pod nowym fundamentem alternatywnego porządku (po)nowoczesności.

Pedagogika krytyczna to dla mnie próba dialektycznego wyjaśnienia, w jaki sposób kapitalistyczne relacje społeczne - czyli kapitał jako forma społeczna (w której imperatywy rynkowe wyznaczają warunki reprodukcji społecznej) ukształtowały uczniów i nauczycieli. Dlaczego ludzkie istnienie jest podporządkowane wymogom zysku? Odpowiednie zależności może ukazać nam tylko materializm historyczny (McLaren 2015: 42).

Tak więc McLaren w sposób stanowczy i niepodlegający dyskusji stwierdza, że materializm historyczny jest koniecznym elementem alternatywnego sposobu myślenia. Jedynym, co można by zarzucić temu sławnemu pedagogowi krytycznemu to to, że sam jest członkiem elity intelektualnej burżuazyjnego społeczeństwa 4 . Dla mnie jest to jednak argument nietrafiony. Najistotniejsze zmiany zachodzą nie w sferze zewnętrznej. Kiedy tłumione Realne (w lacanowskim znaczeniu tego słowa) zaczyna być ujawniane i wywoływane do zaistnienia w dyskursie, to wtedy dopiero mamy do czynienia z prawdziwą rewolucją. Tak więc rzeczywista rewolucja zachodzi wtedy, kiedy tłumione i poniżone formy świadomości klasowej znajdują swoje ujście w obrazoburczych poglądach wspomnianego powyżej McLarena.

\footnotetext{
${ }^{4}$ Należy też wyjść poza skostniały, dogmatyczny marksizm, wyrzekający się samokrytycznego namysłu nad własnym dorobkiem i traktować go raczej jako materiał teoretyczny mogący zainspirować nowy kierunek, zdolny do obalenia globalnej hegemonii kapitalizmu za pomocą wdrażania zdecydowanych mechanizmów ograniczających jego negatywne skutki nawet wtedy, gdy będzie się to łączyć z niezadowoleniem warstw uprzywilejowanych. Co w końcowym rezultacie może zaowocować powstaniem nowego systemu społeczno-politycznego.
} 
Swoisty geniusz tego pedagoga polega na tym, że obrazuje nam to, co ma dopiero nastać. Upadek kapitalizmu już się dokonał, jednak musi zaistnieć chwila, kiedy Realny upadek kapitalistycznego porządku przebije się do świadomości globalnego społeczeństwa. McLaren działa właśnie w tym zakresie, a więc dzięki swym pozornie nierewolucyjnym (w sensie dosłownym) działaniom doprowadza do prawdziwej rewolucji, którą jest powolna zmiana świadomości globalnej w stronę nowego jeszcze nieuformowanego porządku.

Czy kiedy upada jakiś reżim polityczny, nie mamy do czynienia z sytuacją, w której podobnie nie sposób odróżnić jego dwóch śmierci - symbolicznej i realnej? Istnieją takie dziwne epoki, gdy dany reżim jeszcze trwa jakiś czas, choć wiadomo, że jego czas minął. Tak jakby żył on dalej, ponieważ nie zauważył swojej śmierci. Jak pisał Hegel, Napoleon musiał zostać pokonany dwa razy, by to zrozumieć: jego pierwszą klęskę w 1813 roku można było brać jeszcze za zwykły przypadek; dopiero powtórna klęska pod Waterloo dowiodła, że jego odejście wyraża głębszą historyczną konieczność (Žižek 2010: 103).

Wynika z tego, że rzeczywista klęska ma miejsce przed zewnętrznym upadkiem. Jak gdyby dany system, reżim musiał sam zrozumieć własną bezcelowość i bezsensowność w dobie społecznej transformacji. W swojej nowszej książce Che Guevara, Paulo Freire, and the pedagogy of revolution McLaren kontynuuje wcześniejsze rozważania na tematy rewolucyjne. Przejście do pedagogiki Che Guevary, jak ją nazywa McLaren, może być postrzegane jako ciągłe radykalizowanie się poglądów, ale kiedy przyjrzymy się nowszym koncepcjom reprezentowanym przez słynnego pedagoga krytycznego, można dojść do wniosku, że są logiczną konsekwencją jego wcześniejszych wywodów. Kapitalizm ciągle upada, tylko my nie potrafimy jeszcze tego dostrzec. Walka, która rozpoczęła się z momentem jego przyjścia na świat, skończy się dopiero wraz z jego odejściem w niebyt historii. Kryzys może być postrzegany jako pierwsza porażka, następna może być już Waterloo kapitalistycznego porządku społecznego. Teoria skapywania tak ukochana przez bankierów i biznesmenów z Wall Street nie sprawdziła się, bogaci niestety nie są altruistycznymi pocieszycielami biednych, ale ciągle żywią się ich kosztem. Albowiem wartość jest święta. Nie ludzkie życie, nie ideały, nie to żeby ludzie na całym świecie mieli co jeść i mogli godnie żyć tylko to, żeby „gromada wyzyskiwaczy” ciągle pomnażała swój kapitał kosztem nas ubogich.

Internacjonalizm i będąca jego symbolem postać Che Guevary na wieki pozostanie symbolem braterskiej walki przeciwko kapitalistycznemu reżimowi militarnemu i jego propagandzie. Wlewająca odżywcze soki w wyjałowioną przez kapitalistyczną eksploatację glebę nadziei rewolucyjna walka udowodniła na wieki swą skuteczność podczas rewolucji kubańskiej (1956-1959). Uczyniła ona Kubańczyków wolnymi od wpływu kapitału amerykańskiego na przeszło pół wieku. Dopóki istniało ZSRR, dopóty istniało oparcie dla rewolucyjnych ruchów narodowowyzwo- 
leńczych sprzeciwiających się imperializmowi uzasadniającemu swe „pokojowe interwencje" szerzeniem wartości demokratycznych na całym świecie. Pedagogika Che dostrzegała ograniczenia systemu kapitalistycznego nakierowanego jedynie na wyprodukowanie nowej siły roboczej. W dzisiejszych czasach potrzeba krytycznego wychowania nowych pokoleń w duchu antykapitalistycznej krytyki staje się jeszcze silniejsza w obliczu rosnącej siły międzynarodowych korporacji i ich wpływu na kształtowanie mas potulnych robotników. Imperialny kapitalizm USA stawiał bogactwo na równi z zasadami moralnymi, uwalniając ludzi bogatych od potrzeby jakichkolwiek ludzkich uczuć w stosunku do wyzyskiwanych przez nich pracowników. W rzeczy samej uzasadniał on dowolność, z jaką siły burżuazyjne obchodziły się z czarnoskórymi i ludźmi ciężko pracującymi, nadając ich eksploatacji powiew świeżości i mistycyzmu, ponieważ robiąc to, bogaci przyczyniali się do formowania lepszego nowego świata. Che rozumiał, że ci, którzy bronią się przed agresywnymi zakusami kapitału amerykańskiego, czynią to dla dobra życia społecznego, nie pozwalając na to, aby polityka stała się narzędziem w rękach zagranicznego imperium, kontrolowanego przez różne lobby finansowe. W perspektywie pedagogiki Che niezwykle istotne było przekonanie bezbronnych i wyzyskiwanych pracowników na całym świecie do podjęcia przez nich rewolucyjnej walki w skoordynowany na szczeblu międzynarodowym sposób (McLaren 2000: 42-43). O nienawiści i strachu, jakim Amerykanie darzyli rewolucję kubańską, świadczy to, że CIA podjęło kilkaset udokumentowanych zamachów na życie Fidela Castro.

Bezwzględność, z jaką kapitał wykorzystuje swoją siłę do podporządkowywania ludzi imperatywowi interesu i zysku, znajduje swój wyraz w ciągnącej się od stuleci walce o wyzwolenie świadomości klasowej. Kapitał dzieli świat, doprowadza do kryzysów takich jak ten rozpoczęty w 2008 r., a jego konwulsje dotykają z reguły tylko tych najbiedniejszych, tych, którzy nie są w stanie wywrzeć nacisku na polityczne środowiska, wchodzące w niezdrowy mezalians z koryfeuszami globalnego kapitału. Rewolucja jest skutkiem ubocznym ciemiężenia, jest tym, czym jest nagromadzona od setek lat nienawiść w stosunku do „tych lepszych”, którzy pasą się na cierpieniu globalnej biedoty. Ta nienawiść istnieje, nikt przy zdrowych zmysłach tego nie przeoczy. Jednakowoż moim zdaniem McLaren myli się, przywiązując zbyt wielką wagę do klasowej walki rozumianej w sposób dosłowny. Największym wyzwaniem jest nie dopuścić do rzezi, jednak, aby przemiany (niezależnie od tego, jakie będą) zaszły w sposób w miarę pokojowy, niezbędny jest sprzeciw przeciwko działaniom mającym na celu wywołanie trzeciej wojny globalnej. Nie można dopuścić do tego, aby setki, tysiące, miliony ludzi ginęły w obronie tego chorego systemu, który ich zawiódł. Podsycanie nastrojów rewolucyjnych, pseudopatriotycznych i nacjonalistycznych jest w interesie wąskiego kręgu międzynarodowej elity finansowej, która za nic ma życia zwykłych ludzi. W dobie niepokoju prawdziwym bohaterstwem jest nie zabijać, ale odmówić walki w imię niesłusznych interesów ludzi, którzy w tej wojnie nie zamierzają ginąć. Niechaj transformacja będzie pokojowa. 
Wartość wymienna nie jest wypadkową użyteczności danego towaru, przecież wartość użytkowa jest czymś innym niż wymienna, jak twierdził Marks. Użyteczność towaru nie stanowi więc o jego wartości (Wheen 2007: 41). Co więc stanowi o wartości danego towaru? Oczywistym jest, że elementem wspólnym dla różnych towarów jest ilość pracy w nie włożona, a więc to praca, a ściślej przeciętny czas pracy potrzebny do wykonania danego towaru stanowi o wartości danego przedmiotu. Dalej istnieje rozróżnienie również w samej pracy, która - jakżeby inaczej również ma dwoistą naturę. Mianowicie, istnieje praca użytkowa i praca wyabstrahowana. Na czym polega różnica między nimi? Otóż pozostają one w nieustannym i przewlekłym konflikcie, ponieważ nie da się pogodzić użyteczności z wartością wymienną. Coś, co jest idealnie użyteczne - nie zużywa się, jest również w sposób absolutny zabójcze dla kapitału, ponieważ nie ma potrzeby kupna następnego towaru, a więc też wytwarzania jego kolejnych sztuk (Wheen 2007: 42-43). Mamy więc tutaj do czynienia $\mathrm{z}$ jedną $\mathrm{z}$ wielu sprzeczności ukrytą $\mathrm{w}$ podstawowych założeniach systemu kapitalistycznego. Warto, jak mi się wydaje, wyjaśniać niektóre takie zależności, aby stanowisko neomarksistowskie obecne w przywoływanych przeze mnie publikacjach stało się dla nas bardziej klarowne i poprzez to również zrozumiałe.

\section{Rola nauczyciela w podważaniu obecnego systemu wyzysku i konstruowaniu dlań kontrhegemonicznej alternatywy}

Nauczyciele nie powinni być biernymi wykonawcami poleceń płynących ze struktur władzy, urzędnikami państwowymi, profesjonalnymi katami, którzy zabijają ukryte, wrodzone talenty dzieci miast je wydobywać, umacniać i rozwijać. Żeby umożliwić postępowy rozwój społeczeństwa, pedagodzy i nauczyciele powinni nauczać i sami być nauczani, między innymi na studiach, krytycznego sposobu myślenia i analizowania otaczającej ich rzeczywistości społecznej. Warunkiem niezbędnym zaangażowania w procesy odbywające się w społeczności lokalnej i narodowej jest ich zrozumienie. Zapoznanie nauczycieli i wychowawców zarówno z podejściami metodologicznym, jak i z teorią krytyczną pozwoli wyczulić ich na ukryte przejawy funkcjonowania otaczającego nas świata i systemu. Krytycyzm nie może być ograniczony przez nadopiekuńczą władzę, która z chęcią zapewniłaby sobie permanentny i nieusuwalny wpływ na umysły młodych uczniów. Najłatwiej zabić ducha $w$ narodzie poprzez zabicie jego inteligencji. Najłatwiej zniszczyć i wymazać to, co tworzy się największym wysiłkiem i pracą u podstaw, czyli jakość człowieka. To właśnie ta pogarda dla jakiejkolwiek pracy umysłowej charakteryzuje społeczeństwo polskie, które w swej masie z chęcią zaprzedaje ideały wolności i wyrafinowania umysłowego. Bez szacunku dla myślenia, bez prawości intelektualnej nie ma mowy o tworzeniu kultury (Brzozowski 1983: 41-42). Nie można do tego dopuścić, aby gloryfikacja bezwzględnego systemu władzy stała się nieusu- 
walną funkcją edukacji. Z tego samego powodu, mimo panującego w naszym państwie negatywnego nastawienia do Marksa i jego myśli (oczywiście stwierdzam to w sensie ogólnym, a nie zasadniczym. Jest wiele osób potwierdzających wartość marksistowskiego i neomarksistowskiego uniwersum), należy zachęcać nauczycieli do krytycznego nauczania i ustosunkowywania do panującej ideologii. Wpisywanie się w ustalone ramy jest zawsze czymś łatwiejszym niż wyjście w pole. Sądzę jednak, że nieodłącznym elementem zawodu nauczyciela jest obowiązek walki o niezależność młodych umysłów, jak i walki o wartości uniwersalne, takie jak wolność, równość i braterstwo, które nie powinny się uginać pod egoistycznymi żądaniami autokratów. Krytycyzm powinien więc nie tylko stanowić pewną nieukonstytuowaną zasadę tegoż zawodu, co stać się jego elementem zasadniczym. Dobry nauczyciel to krytyczny nauczyciel, analizujący nie tylko otaczający go świat społeczny, ale i własną pozycję wobec panującego systemu kapitalistycznego i jego wymogów. Jeśli ludzkie życie ma być tyle samo warte - to czemu jedni umierają w luksusie, a inni w nędzy? Czemu świat dzieli się na gorszych i lepszych ludzi? Ludzi, którym trzeba się kłaniać i których nie wolno znieważać, i takich, których można obrażać do woli, bić i poniżać, nie obawiając się żadnych konsekwencji. W tej chwili nasz świat staje się takim światem, bezwzględnym i ograniczającym wartość człowieka do zawartości jego portfela. Światem, w którym młode dziewczęta zmuszane są do prostytucji już na studiach, aby mieć pieniądze na własne utrzymanie. To miejsce, w jakim żyjemy, jest niczym więcej jak „kloaką” przesiąkniętą cynizmem i smutkiem tych, którym nie powiodło się w globalnym wyścigu szczurów. W bitwie o lepsze jutro to edukacja jawi się jako sfera zasadnicza, na polu której rozgrywa się walka o wpływ na oprogramowanie nowych uczestników teatru konsumpcjonizmu.

Edukacja stanowi kluczowy proces „generowania relacji kapitału”, gdyż „łączy ogniwa łańcucha, którym nasze dusze przykute są do kapitału", lub - by posłużyć się inną metaforą - edukacja to jedna z lin ringu, na którym toczy się napędzająca współczesną historię wściekła walka między pracą a kapitałem, czyli „walka klas”. Szkoły w ogromnym stopniu przyczyniają się do podtrzymywania i wytwarzania stosunków klasowych, „brutalna relacja kapitał-praca stanowi rdzeń kapitalistycznego społeczeństwa i kapitalistycznego rozwoju" (McLaren 2015: 44).

Smutna rzeczywistość, w której zmuszeni jesteśmy żyć, oparta jest na ciągłej i nieustającej relacji wyzysku i władzy, która ukryta za postulatami pozornego człowieczeństwa i humanitaryzmu razi swoją okrutną, nieznającą współczucia logiką. Szkoły to nic innego jak laboratoria kapitalizmu i jego narzędzia służące indoktrynacji ciężko pracujących mas. Edukacja jawi się w tym ujęciu jako fabryka, w której surowcem są małe dzieci, a produktem końcowym mają być młodzi ludzie dostosowani do zmiennych potrzeb rynku pracy. Pozorna wolność w systemie 
kapitalistycznym oznacza teoretyczne i praktyczne zniewolenie edukacji i życia społecznego, jak również kulturowego przez nieubłagane stosunki klasowej dominacji. Nauczyciele są $\mathrm{w}$ nim tylko robotnikami na taśmie montażowej fabryki zwanej szkołą, których zadaniem jest nie tyle rozwój i „właściwe” ukierunkowywanie potencjału uczniów, co urabianie ich na określoną modłę. Rewolucja w szkołach musi więc wynikać nie tyle z odgórnej, co z oddolnej inicjatywy robotników-nauczycieli i niezgody na klasowy charakter edukacji. Ten, kto wygra walkę o umysły uczniów, wygra też walkę o przyszły kształt i charakter naszego społeczeństwa. W kontekście radykalnej teorii krytycznej to, co dzieje się w naszym kraju, a więc nasycenie edukacji ideami nacjonalistycznymi, ksenofobicznymi, pseudopatriotycznymi, klerykalnymi, kapitalistycznymi powoduje, że jest ona skorumpowanym systemem indoktrynującym uczniów i przymuszającym ich do wtłoczenia się w sztywne formuły „bezpłatnej” i „powszechnej” edukacji, a raczej indoktrynacji.

Klasowe szkolnictwo współczesności stosuje symboliczny i praktyczny apartheid oparty na zamożności poszczególnych członków społeczeństwa. Jest oczywistością, że uczniowie nie będą traktowani równo w systemie edukacyjnym społeczeństwa, w którym ideały demokratyczne zostały zaprzepaszczone na rzecz prawa tworzonego w taki sposób, aby chroniło ludzi bogatych. To prawda, że to, czego nauczamy w szkole, ma zasadniczy wpływ na życie ludzi. Dlatego narracje antykapitalistyczne mają prawo i muszą być obecne w szkole, jeśli chcemy dać uczniom szansę na zbudowanie alternatywnego sposobu myślenia względem wiodącej arbitralności kulturowej (McLaren 2015: 45-46). Dyskurs wolności i nadziei musi przeniknąć do szkół, aby wychodzili z niej obywatele świadomi obowiązujących stosunków władzy i gotowi je zmieniać. W Polsce również istnieje lumpenproletariat miejski. Dzielnice bogactwa i nędzy. Ci ludzie muszą dostać w ręce narzędzia intelektualne - język możliwości i krytyki (tamże: 66), pozwalające im zrozumieć mechanizmy wykluczenia narzucające im ich podległą rolę. Organizacja ludzi pracy musi rozpocząć się od budowania siły związków zawodowych i zaplecza instytucjonalnego pozwalającego zaistnieć na scenie politycznej formacji politycznej odwołujących się wprost do retoryki neomarksistowskiej dążącej do ograniczenia władzy elity finansowej oraz budowania międzynarodowych sojuszy w Unii Europejskiej i poza jej granicami w celu ograniczenia władzy kapitału nad życiem ludzi i włączenia jak największej jego części w obszar dobra wspólnego.

W ujęciu przedstawianym przez McLarena edukacja jawi się jako bardzo „perwersyjny" system. Używam słowa perwersyjny, ponieważ charakteryzuje się on tym, że niejako realizuje odwrotny cel niż ten, który oficjalnie podaje ${ }^{5}$. Pod szyldem pozornej równości promuje praktyczną nierówność i klasowość społeczeństwa. Zamiast egalitaryzmu zapewnia sukces dzieciom z bogatszych, lepiej wykształco-

\footnotetext{
5 P. Sloterdijk (2014), cała książka jest znakomita, ale odnośnie do perwersji systemu szkolnego szczególnie istotne są strony 597-603.
} 
nych rodzin, a tych z biedniejszych skazuje na przymusową (bo związaną z koniecznością przeżycia) pracę na nisko płatnych i postrzeganych jako "gorsze” stanowiskach pracy lub szybkiego i bezpowrotnego wyjazdu za granicę. Nie wiem, jak sądzą inni pedagodzy, ale ja zauważam pewną rację w postulatach kanadyjskiego pedagoga krytycznego. Jest coś perwersyjnego w tym, że rodząc się, jako małe dziecko masz już wielkie prawdopodobieństwo tego, że będziesz sprzątał ulice i pielił trawniki bogatszych ludzi. To tak jakby to małe dziecko rodziło się w więzieniu, gdzie jego przyszłe role są już w dużym stopniu określone, a prawdopodobieństwo tego, że jego los potoczy się inaczej jest niewielkie. Taki świat, który tworzą tacy, a nie inni ludzie, rzeczywiście chyba powinien rozwijać się w kierunku jakiejś zmiany - jeśli chcemy dalej egzystować jako uprzywilejowany gatunek w świecie stworzenia. W Stanach Zjednoczonych postępuje ciągle proces polaryzacji społeczeństwa. Jak pisze laureat Nagrody Nobla w dziedzinie ekonomii Joseph Stiglitz:

[W] USA ten wskaźnik [równości szans] jest wyraźnie niższy [niż w Wlk. Brytanii i Danii - D.Ch.] (tylko 58 procentom dzieci z tej grupy najbiedniejszych rodzin udaje się wyjść z ubóstwa) i najczęściej awans ten jest bardzo skromny. Dzieci prawie dwóch trzecich osób należących do najbiedniejszych 20 procent Amerykanów będą należały do biedniejszych 40 procent populacji - co daje wartość o 50 procent wyższą niż gdyby szanse awansu były równe (Stigilitz 2015: wersja mobi, loc. 1291).

Tak więc edukacja nie jest wolna ani równa. Jest podporządkowana kapitalistycznym koryfeuszom prawdy i interesom przez nich reprezentowanym. Nie podoba mi się jednak w poglądach pedagogów krytycznych o proweniencji amerykańskiej przekonanie, że tylko dzięki rewolucji można odnaleźć właściwą drogę. Leninowskie i stalinowskie praktyki pokazały, do czego prowadzi bezrozumna rewolucja kolektywu. Wydaje mi się (i tu moim zdaniem ukazuje się słaby punkt tej teorii), że obecny jest tu pewien ładunek fanatyzmu podobnego w dużej mierze, że fanatyzmowi religijnemu. Moim zdaniem właściwsza i bezpieczniejsza (nawet gdy w dużym stopniu zgadzamy się z wnioskami McLarena i innych pedagogów krytycznych) jest droga reform i konstruktywnego wprowadzania w życie polityki zmniejszania różnic, opodatkowania najbogatszych, zakazu transferu zysku z kraju - wszystkie takie zmiany należy jednak przemyśleć i zastanowić się nad tym, czy rzeczywiście będą działać i czy i na jakich zasadach należy je wprowadzić. Jest prawdą ogólnie znaną, że rewolucje nie wybuchają wtedy, gdy jest najgorzej, lecz wtedy, gdy sytuacja zaczyna się trochę poprawiać. Nauczyciele i pedagodzy powinni konstruować dyskurs nadziei i społecznego sprzeciwu, ale zawsze muszą też mieć na uwadze dobro wspólne i dobrobyt szerokich mas społecznych. 


\section{Podsumowanie}

Twórczość myślicieli, którzy postrzegają edukację jako narzędzie emancypacji i zapobiegania procesowi narastania nierówności społecznych, również zabarwiona neomarksistowsko, jest niewątpliwie cennym wkładem w myśl pedagogiczną, niektórych może odstręczać jej często nazbyt rewolucyjny (w sensie rewolucji rozumianej jako walka wręcz) charakter. Jednak ważne jest, aby ta niewielka wada nie przesłaniała ogromnej ilości pozytywów, jakie są w niej obecne. Po pierwsze przywraca ona jako wartościowe instrumentarium teorii marksistowskiej, która po przedstawieniu jej w rozumieniu czołowych pedagogów krytycznych takich jak Giroux i McLaren, nie wydaje się mieć już tak negatywnego charakteru. Uważam, że pedagogika krytyczna stanowi szczególnie cenną orientację teoretyczną na rynku polskim, ponieważ przedstawia w nowym świetle tak zdyskredytowaną u nas przez okres PRL-u myśl Karola Marksa6 ${ }^{6}$ W tym artykule starałem się unaocznić kluczowe zagadnienia poruszane przez myśl krytyczną wobec obecnego reżimu władzy i wiedzy inspirującą się szeroko rozumianą tradycją marksistowską. Prace z obrębu pedagogiki krytycznej zasługują na to, aby je tłumaczono na język polski i rozpowszechniano ruch metaanalizy edukacji postulowany przez tę wyjątkową, interdyscyplinarną subdyscyplinę pedagogiczną. Warto czytać i analizować prace pedagogów krytycznych, otwierają one bowiem oczy na zjawiska, mechanizmy, które w innym wypadku są często po prostu bezmyślnie wdrażane i nie spotykają się z żadnymi próbami oporu pomimo swojej niewątpliwej szkodliwości. Pokazanie, w jaki sposób ideologia neoliberalna bezkrytycznie adaptowana wpływa na proces kształcenia i wychowania późniejszych pokoleń, jest czymś wprost bezcennym. Sądzę, że walka o przyszłość tego świata (jakkolwiek górnolotnie to brzmi) rozegra się na terenie szkół i w edukacji. Wynika to w prosty sposób z tego, co pisze zarówno Giroux, jak i McLaren. Wpajanie dzieciom walki o sukces i tym samym zabijanie $\mathrm{w}$ nich empatii jest immanentnym elementem systemu kapitalistycznego. Zysk nielicznych buduje się na wyzysku mas. Przegrani nie są równi zwycięzcom w kapitalistycznym procesie produkcji. Teza, że marksizm jest już zużyty po przeczytaniu prac rewolucyjnych pedagogów krytycznych jest już nie do obronienia. Może istnieje poważna alternatywa dla ideologii kapitalistycznej? Jak dotąd nie udało się sfalsyfikować teorii Marksa - udało się ją jedynie wyśmiać, odrzucić jak nędzny twór niestanowiący realnej alternatywy. Prosocjalna ewolucja kapitału jest jak dotąd jedyną sensowną odpowiedzią dawaną przez obecny system na problemy ludzkości, ale to nie rozwiązuje jej problemów, potrzebna jest przemyślana ustrojowa rewolucja - w miarę możliwości bez ofiar. Jeżeli Marks miał rację, to kapitał, kręcąc się w kółko jak pasożyt, będzie potrzebował ciągle coraz to nowych obszarów eksploatacji. Ideologia kapitalistyczna nie przezwyciężyła ideologii marksi-

\footnotetext{
${ }^{6}$ Nie chodzi tu nawet o Marksa, ale o tych wszystkich myślicieli zachodnich, którzy wychodząc od inspiracji myślą marksistowską, stworzyli cenne prace teoretyczne nieobecne po dziś dzień w głównym dyskursie naukowym w Polsce.
} 
stowskiej tylko usiłuje ją wyminąć, obrzydzić, uznać za niewartą rozwoju. Marksizm jako jedyny tworzy alternatywną dla ideologii kapitalistycznej wizję rozwoju ludzkości. Nie próbuje on (co niezwykle istotne) jej rozwijać lub reformować. Być może z martwego pnia, za jaki panująca, hegemoniczna burżuazyjna myśl uznała dzieło Marksa, mogą wyrosnąć liczne gałęzie symbolizujące nowe rozwojowe nurty myślenia, niepotrzebujące kapitalistycznego porządku, posługujące się inną zasadą - metodą. Nawet poprzez edukację kapitalizm uczy, że odczłowieczanie, utowarowienie innych jest pozytywną, społeczną zasadą. Jeśli uczniowie zdołają uprzedmiotowić swych rywali, to znaczy, że wygrali z nimi w wyścigu o bycie lepszymi. Stali się sprawniejszymi manipulatorami sterującymi innymi ludźmi. Analizowanie metanarracji konstruowanej przez pedagogikę krytyczną rzuca nowe światło na pozornie niewinne techniki stosowane w edukacji, które uprzedmiotawiają podmioty ludzkie, sprowadzając je do rangi zwyczajnych towarów potrzebnych na rynku pracy. Obnaża też nieoczywistość codziennej praktyki szkolnej i społecznej, będąc wspaniałym wprowadzeniem do krytycznego i nonkonformistycznego myślenia. Pedagogikę krytyczną należy zatem poznawać i stosować, aby stać się godnym miana transformatywnego intelektualisty. W uniwersytetach i akademiach pedagogicznych nie powinno się pomijać lub marginalizować tej subdyscypliny, ale należy ją właśnie twórczo rozwijać i czynić jedną z głównych gałęzi rozwoju pedagogiki, szczególnie istotną ze względu na swoją zdolność do krytycznej metaanalizy ideologicznych narracji, chcących zawładnąć systemami edukacyjnymi współczesnych państw, oraz swój interdyscyplinarny i wolnościowy charakter.

\section{Bibliografia}

Bourdieu P., Passeron J. C. (2006) Reprodukcja. Elementy teorii systemu nauczania, tłum. E. Neyman, Warszawa, Wydawnictwo Naukowe PWN.

Brzozowski S. (1983) Legenda Młodej Polski. Studya o strukturze duszy kulturalnej, Kraków-Wrocław, Wydawnictwo Literackie.

Feyerabend P. K. (1996) Przeciw metodzie, tłum. S. Wiertlewski, Wrocław, Wydawnictwo Siedmioróg.

Giroux H. A. (2010) Naga pedagogia i przekleństwo neoliberalizmu: przemyśleć edukację wyższq jako praktykę wolności, tłum. P. Zamojski w: H. A. Giroux, L. Witkowski, Edukacja i sfera publiczna. Idee i doświadczenia pedagogiki radykalnej, Kraków, Oficyna Wydawnicza „Impuls”, s. 281-298.

Giroux H. A. (2010) Odzyskanie uniwersytetu jako demokratycznej sfery publicznej (by to, co pedagogiczne, było bardziej polityczne), tłum. M. Jaworska-Witkowska w: H. A. Giroux, L. Witkowski, Edukacja i sfera publiczna. Idee i doświadczenia pedagogiki radykalnej, Kraków, Oficyna Wydawnicza „Impuls”, s. 265-280. 
Giroux H. A. (2011) Zombie politics and culture in the age of casino capitalism, New York, Peter Lang Publishing.

Kuhn T. S. (2009) Struktura rewolucji naukowych, tłum. H. Ostromęcka, Warszawa, Wydawnictwo ALETHEIA.

Levidow L. (2009) Neoliberalne plany dla szkolnictwa wyższego w: Neoliberalizm przed trybunałem, A. Saad-Filho, D. Johnson (red.), tłum. J. P. Listwan, Warszawa, Książka i Prasa, s. 247-258.

McLaren P. (2000) Che Guevara, Paulo Freire, and the pedagogy of revolution, Rowman \& Littlefield Publishers.

McLaren P. (2015) Życie w szkołach. Wprowadzenie do pedagogiki krytycznej, tłum. A. Dziemianowicz-Bąk, J. Dzierzgowski, M. Starnawski, Wrocław, Wydawnictwo Naukowe Dolnośląskiej Szkoły Wyższej.

Popper K. R. (1977) Logika odkrycia naukowego, tłum. U. Niklas, Warszawa, Wydawnictwo Naukowe PWN.

Shaikh, A. (2009) Ekonomiczna mitologia neoliberalizmu w: Neoliberalizm przed trybunałem, A. Saad-Filho, D. Johnson (red.), tłum. J. P. Listwan, Warszawa, Książka i Prasa, s. 73-86.

Sloterdijk P. (2014) Musisz życie swe odmienić, tłum. J. Janiszewski, Warszawa, Wydawnictwo Naukowe PWN.

Stiglitz J. S. (2015) Cena nierówności. W jaki sposób dzisiejsze podziały społeczne zagrażają naszej przyszłości, tłum. R. Mitoraj, Warszawa, Krytyka Polityczna, wersja mobi.

Śliwerski B. (2012) Pedagogika ogólna. Podstawowe prawidłowości, Kraków, Oficyna Wydawnicza „Impuls”.

Tormey S., Townshend J. (2010) Od teorii krytycznej do postmarksizmu, tłum. K. Szumlewicz, Warszawa, Wydawnictwo Naukowe PWN.

Wheen F. (2007) Marks Kapitał. Biografia, tłum. P. Laskowski, Warszawa, Warszawskie Wydawnictwo Literackie MUZA SA.

Žižek S. (2010) Lacan. Przewodnik Krytyki Politycznej, tłum. J. Kutyła, Warszawa, Wydawnictwo Krytyki Politycznej, wydanie II rozszerzone.

https://www.theguardian.com/global-development/2017/jan/16/worlds-eightrichest-people-have-same-wealth-as-poorest-50 [dostęp 09.10.2017]. 